\title{
Ribosomal RNA genes and the B chromosome of Brachycome dichromosomatica
}

\author{
TAMZIN M. DONALD, CAROLYN R. LEACH*, ANGELA CLOUGH AND \\ JEREMY N. TIMMIS \\ Department of Genetics, The University of Adelaide, South Australia 5005, Australia
}

\begin{abstract}
Fluorescence in situ hybridization (FISH) with biotinylated rDNA revealed the presence of an rRNA gene cluster on both the A and B chromosomes of Brachycome dichromosomatica, an Australian native ephemeral plant of the arid regions of south-eastern Australia. This species contains only two pairs of A chromosomes and up to three B chromosomes. The regular attachment of the B chromosome to a nucleolus suggests that these ribosomal RNA genes are transcribed. Southern hybridization of DNA from $0 B$ and $+B$ plants digested with a variety of restriction enzymes indicates that the rRNA genes on the $\mathrm{A}$ and $\mathrm{B}$ chromosomes are the same in sequence and methylation status.
\end{abstract}

Keywords: B chromosomes, Brachycome dichromosomatica, in situ hybridization, nucleolar organizer, rRNA genes.

\section{Introduction}

B chromosomes are dispensable, supernumerary chromosomes that do not recombine with the A chromosomes and follow their own evolutionary pathway (Beukeboom, 1994). These supernumerary chromosomes are present in the genomes of a large proportion of individuals in wild populations of many plant and animal species. Although B chromosomes (Bs) have been found most commonly among the species of certain groups, in particular grasses and grasshoppers, recently, to some extent because of the use of new cytological techniques, they have been discovered in groups where they were previously unknown. Bs are frequently found in rodents (Yonenaga-Yassuda et al., 1992), marsupials (McQuade et al., 1994) and many fish species. A recent report summarizes the observations in 21 different fish species and indicates finding B chromosomes in 87.5 per cent of the samples studied (Salvador \& MoreiraFilho, 1992). Furthermore, a study of South African grasses reported Bs in $>70$ per cent of species, where at least 10 specimens were examined (J. J. Spies \& H. $\mathrm{Du}$ Plessis, personal communication). Bs have also been described in fungi (Hizume et al., 1991; Miao et al., 1991). It has been concluded that they probably occur in all taxa over a wide geographical distribution

*Correspondence.
(Beukeboom, 1994). A spectrum of numerical types is usually found in populations and sometimes several derivatives of a standard fragment type may arise by deletion or centromere misdivision (López-León et al., 1993).

Although Bs never appear on a linkage map they are not genetically inert and it is known that some carry functional genes. For example nucleolar organizer regions (NORs), the sites of ribosomal $18 \mathrm{~S}$ and $25 \mathrm{~S}$ RNA genes, have been identified on Bs in about 20 species (reviewed by Green, 1990). A further four species are cited by Mabuchi (1991) and others have been recently described by Li et al. (1991), YonenagaYassuda et al. (1992), Kiknadze et al. (1992) and Suja et al. (1993). In some cases the NORs were identified by silver staining (e.g. Maluszynska \& Schweizer, 1989) and this method is frequently assumed to reflect transcriptional activity of the rRNA genes.

Brachycome dichromosomatica is an Australian native ephemeral plant of the arid regions of southeastern Australia which contains only two pairs of A chromosomes and up to three B chromosomes (Carter, 1978). Here we report the localization of rRNA genes in this species by fluorescence in situ hybridization (FISH) with biotinylated rDNA. Gene clusters were observed at the cytologically visible NOR of the larger A chromosome and at the satellited end of the B chromosome. The rRNA genes of the B chromosome were shown to be similar in sequence and methylation 
at CCGG sites to those on the A chromosome. The B chromosome was often seen associated with a nucleolus at diplotene of meiosis.

\section{Materials and methods}

\section{Plant material}

Brachycome dichromosomatica has been maintained in the glasshouse at the University of Adelaide for some years. The plants used were descendants of original plant and seed material collected from three areas near Port Augusta in South Australia during the spring of 1989 and 1990 (John et al., 1991). Brachycome dichromosomatica is an outbreeding species and abundant seed can readily be obtained by rubbing flowering heads together. Mature seeds were soaked, dissected and transferred to moist filter paper in petri dishes. After about 1 week tiny seedlings were transferred to potting compost in seedling trays, covered with a small vial and placed in a controlled temperature growth cabinet. In a further 4-6 weeks seedlings were large enough for the collection of root tips and transfer to larger pots in the glasshouse. Flowering occurred quite rapidly and continued throughout the life of the plant, which is about 6 months.

Root tips were treated with 0.075 per cent colchicine for $3-4 \mathrm{~h}$, fixed for $1 \mathrm{~h}$ in ice-cold methanol:glacial acetic acid $(3: 1)$ and transferred to 70 per cent ethanol for storage at $4^{\circ} \mathrm{C}$ until required. For squash preparations root tips were hydrolyzed and stained in acetic orcein. For in situ hybridization root tips were treated with 45 per cent acetic acid for several hours prior to squashing. The quality of the preparation was examined using phase contrast microscopy. After removal of the coverslips, the slides were air-dried, washed in 70 per cent, 95 per cent and 100 per cent ethanol ( $30 \mathrm{~min}$ each) and finally dried and stored in a desiccator. Slides were used within 1 week of preparation. For meiotic preparations, fresh pollen mother cells were squashed in acetic orecin.

\section{Silver staining}

The method of Maluszynska \& Schweizer (1989) was modified as follows. Slides were incubated for $10 \mathrm{~min}$ in $0.01 \mathrm{M}$ borate buffer ( $\mathrm{pH} 9.2$ ), $200 \mu \mathrm{L} \mathrm{1:1} \mathrm{w/v}$ $\mathrm{AgNO}_{3}$ in water was Millipore filtered and added to each slide, which was covered with a nylon mesh and incubated at $65^{\circ} \mathrm{C}$ for up to $2 \mathrm{~h}$. Slides were rinsed,

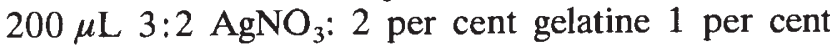
formic acid (pH 3.0) added and incubated for $10 \mathrm{~min}$. If necessary slides were counter-stained with acetic orcein.

(c) The Genetical Society of Great Britain, Heredity, 74, 556-561.

\section{In situ hybridization}

Slides were treated with $200 \mu \mathrm{L}$ RNAse $(199 \mu \mathrm{g} / \mathrm{mL})$ in a closed box containing absorbent paper moistened with $2 \times \mathrm{SSC}$ ( $\mathrm{SSC}$ is $0.15 \mathrm{M} \mathrm{NaCl}, 0.015 \mathrm{M} \mathrm{Na}$-citrate, $\mathrm{pH} 7.0$ ) at $37^{\circ} \mathrm{C}$ for $60 \mathrm{~min}$, washed in $2 \times \mathrm{SSC}$ at room temperature and dehydrated in 70 per cent, 95 per cent and 100 per cent ethanol before air drying. The material on the slides was denatured for $2.5 \mathrm{~min}$ in denaturation mix (70 per cent deionized formamide, $2 \times \mathrm{SSC}$ ) at $70^{\circ} \mathrm{C}$, dehydrated in 70 per cent and 95 per cent ethanol at $-20^{\circ} \mathrm{C}$ and then air dried. For hybridization, $20 \mu \mathrm{L}$ rDNA probe (the entire rRNA gene repeat unit from cotton, biotin-labelled using nick translation), denatured for $10 \mathrm{~min}$ at $70^{\circ} \mathrm{C}$ in hybridization mix (7.5 per cent $(w / v)$ dextran sulphate, $1.5 \times$ SSC, 37.5 per cent deionized formamide, 0.075 per cent Tween 20) was added to each slide. Slides were left overnight at $37^{\circ} \mathrm{C}$ in a closed box containing absorbent paper moistened with $2 \times \mathrm{SSC}$, washed in 50 per cent formamide in $2 \times \mathrm{SSC}$ at $42^{\circ} \mathrm{C}(2 \times 10 \mathrm{~min})$, $2 \times \mathrm{SSC}$ at room temperature $(2 \times 5 \mathrm{~min})$ and rinsed in $1 \times$ SSC. Slides were then rinsed in 0.05 per cent Tween 20 in $4 \times$ SSC for $3 \mathrm{~min}$, pre-incubated in $100 \mu \mathrm{L} 1$ per cent bovine serum albumen (BSA) in $4 \times$ SSC for $10 \mathrm{~min}$ and treated with $60 \mu \mathrm{L}$ AvidinFITC $(5 \mu \mathrm{g} / \mathrm{mL}$ in 1 per cent BSA and $4 \times \mathrm{SSC})$ for $20 \mathrm{~min}$. For amplification, slides were washed in 0.05 per cent Tween 20 in $4 \times$ SSC for $2 \times 5$ min and treated with $1 \mu \mathrm{g} / \mathrm{mL}$ biotinylated goat anti-avidin in 1 per cent BSA and $4 \times$ SSC for $20 \mathrm{~min}$ and then washed in 0.05 per cent Tween 20 in $4 \times$ SSC for $2 \times 5$ min. The detection and amplification steps were repeated as many times as required. Slides were given a final rinse in $2 \times \mathrm{SSC}$ for $2 \mathrm{~min}$, then in $0.15 \mathrm{M}$ phosphate buffered saline $(\mathrm{pH} \mathrm{7.4)}$ for $2 \times 2$ min before the application of $20 \mu \mathrm{L}$ of stain $(1 \mu \mathrm{g} / \mathrm{mL}$ propidium iodide in $10 \mathrm{mg} / \mathrm{mL} p$-phenylenediamine, 90 per cent $\mathrm{v} / \mathrm{v}$ glycerol). Preparations were examined using fluorescence microscopy with light at $\lambda 450-490 \mathrm{~nm}$. Photographs were taken with Kodak Ektachrome film, manipulated using Adobe Photoshop ${ }^{\mathrm{TM}}$, and printed on a Kodak XLT 7720 colour printer.

\section{DNA isolation and manipulation}

High molecular mass DNA was prepared (Scott \& Possingham, 1980) from $B$. dichromosomatica plants containing 0 and $2 \mathrm{~B}$ chromosomes. Samples were digested with a range of restriction enzymes, fragments were resolved on 0.8 per cent agarose gels, Southern blotted (Southern, 1975) and hybridized with ${ }^{32} \mathrm{P}$ labelled $18 \mathrm{~S}$ and $25 \mathrm{~S}$ fragments of pCU18, a cloned rRNA gene repeat unit from cucumber (Kavanagh \& Timmis, 1986), and autoradiographed. Restriction 
enzymes and other DNA modifying enzymes were used under conditions specified by the supplier (Boehringer-Mannheim).

\section{Results}

The homologous pairs of A chromosomes of the accession of $B$. dichromosomatica used in these experiments are readily distinguishable cytologically (Fig. 1a) and the larger pair, which is nearly metacentric, has a prominent secondary constriction about mid-way along the longer arm. The B chromosomes are smaller metacentrics which show a secondary constriction at the distal end of one arm (Fig. 1b). Silver-stained

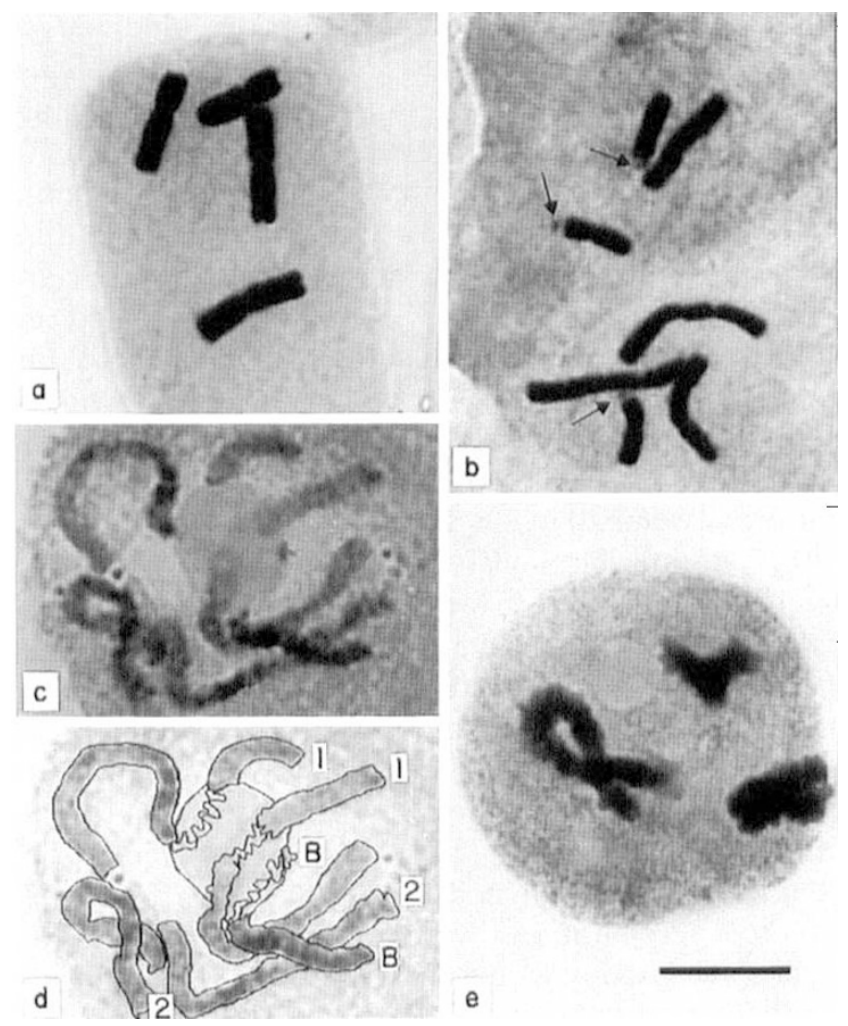

Fig. 1 Chromosome preparations from Brachycome dichromosomatica. Mitotic c-metaphase in orcein-stained root tip cells from plants containing (a) zero B chromosomes and (b) three $\mathrm{B}$ chromosomes (indicated with arrows). Secondary constrictions may be seen on the long arm of the larger A chromosome and at one distal end of each B chromosome. (c) Silver-stained mitotic chromosomes in late prophase showing attachment of $\mathrm{A}$ and $\mathrm{B}$ chromosomes to the nucleolus. (d) An explanatory drawing showing our identification of the chromosomes in (c). (e) Late diplotene or diakinesis in a pollen mother cell of a plant with two B chromosomes showing attachment of the nucleolar organizing bivalent and the B chromosome bivalent to the nucleolus. The line in (e) represents $10 \mu \mathrm{m}$ for all photographs in the figure. metaphase cells in root tips sometimes show stained regions which correlate with these secondary constrictions but the tissue is not amenable to good quality, reproducible preparation (results not shown). The silver- and orcein-stained late mitotic prophase (Fig. $1 \mathrm{c}, \mathrm{d})$ shows both homologues of chromosome 1 and a single B chromosome attached to the same nucleolus. The B chromosomes may frequently be seen attached or adjacent to the nucleolus at diplotene of meiosis in pollen mother cells (Fig. 1e).

In situ hybridization with a biotinylated rRNA gene probe (Fig. 2a,b) reveals the presence of ribosomal RNA gene clusters at the NOR on the larger of the two pairs of $\mathrm{A}$ chromosomes and also gives a strong signal
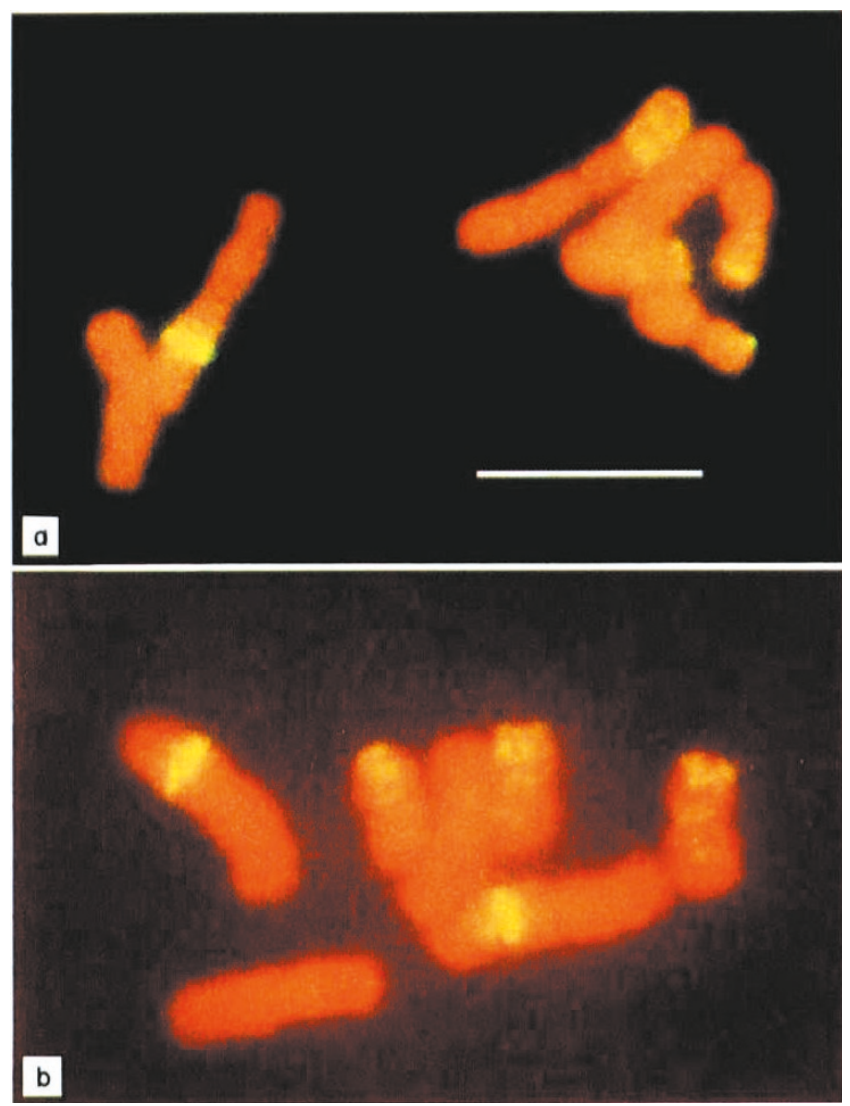

Fig. 2 Brachycome dichromosomatica chromosomes hybridized in situ with a plant rRNA gene probe and viewed under 450-490 $\mathrm{nm}$ light. Two propidium iodide-stained (red fluorescence) mitotic c-metaphase spreads (a,b) from a plant containing three $\mathrm{B}$ chromosomes after in situ hybridization with a biotinylated plant rRNA gene probe and detection with FITC-labelled avidin and anti-avidin antibodies. Yellow fluorescence of the FITC-labelled molecules indicates that the probe bound to the two NORs on the larger chromosome pair and to the satellited region of each $\mathrm{B}$ chromosome. The line in (a) represents $10 \mu \mathrm{m}$ for both photographs in the figure. 
at the satellited end of each B chromosome. Consistent levels of signal were found on $\mathrm{B}$ chromosomes in $1 \mathrm{~B}$, $2 \mathrm{~B}$ and $3 \mathrm{~B}$ plants, but the plants in this experiment all originated from a single population. It is therefore possible that the B chromosomes in the material used are all identical. A continuous polymorphism observed in some B chromosomes in Eyprepocnemis plorans is thought to be attributable to variation in the number of rDNA cistrons present in these chromosomes (M. Dye, J. M. Rubio, C. García de la Vega, C. Juan, J. Gosálvez, and C. López-Fernández, personal communication). In $B$. dichromosomatica the signals observed on chromosome 1 were very unequal in some plants (data not shown) suggesting that different numbers of rRNA gene repeats are found at different $\mathrm{A}$ chromosome NORs within this plant population.

The amount of in situ hybridization to B chromosomes compared with A chromosomes suggests that a substantial proportion of the rRNA genes in individual plants, which may contain up to $3 \mathrm{~B}$ chromosomes, must reside on the $\mathrm{B}$. This finding offers an opportunity to investigate restriction site differences between the A and B chromosome rRNA gene clusters. Samples of DNA were therefore prepared from $0 B$ and 2B plants, restricted with a variety of restriction enzymes and a Southern blot probed with an rRNA gene probe (Fig. 3). The pattern of hybridization to the probe appears identical in $0 \mathrm{~B}$ and $2 \mathrm{~B}$ DNA for all restriction enzymes used, indicating that the $\mathrm{B}$ chromosome clusters are indistinguishable from those on the $\mathrm{A}$ chromosome in both sequence and restriction fragment lengths.

The Southern hybridization (Fig. 3) indicates that genomic DNA from $\mathrm{OB}$ and $2 \mathrm{~B}$ plants contains multiple repeats of rRNA genes which show similar patterns of hybridization with $18 \mathrm{~S}$ and $25 \mathrm{~S}$ probes. The two major hybridizing bands in Fig. 3, tracks 5 and 6 , together indicate a probable size of $10.95 \mathrm{~kb}$ for the B. dichromosomatica ribosomal repeat unit. The minor band at $4.95 \mathrm{~kb}$ suggests minor heterogeneity within the repeat cluster in both $\mathrm{OB}$ and $2 \mathrm{~B}$ genomes. The enzymes HpaII and MspI are isoschizomers, each recognizing the sequence $5^{\prime}-\mathrm{CCGG}-3^{\prime}$, but restriction is prevented if the inner or outer cytosine, respectively, is methylated. The lack of digestion of rDNA by $\mathrm{HpaII}$ indicates that $\mathrm{C}^{\mathrm{m}} \mathrm{CGG}$ is present at almost all CCGG sites in the rDNA. The minor bands at $9.4 \mathrm{~kb}$ and $17.7 \mathrm{~kb}$ show that one CCGG site on a minority of genes is digestible by HpaII and that these minor bands reflect the presence of rare repeat-sized fragments and the dimeric repeat, respectively. The multiple bands seen in Fig. 3, tracks 1,2 show that ${ }^{\mathrm{m}} \mathrm{CCGG}$ is much rarer in the rDNA of $B$. dichromosomatica. A summation of approximately 14 bands gives a total of over

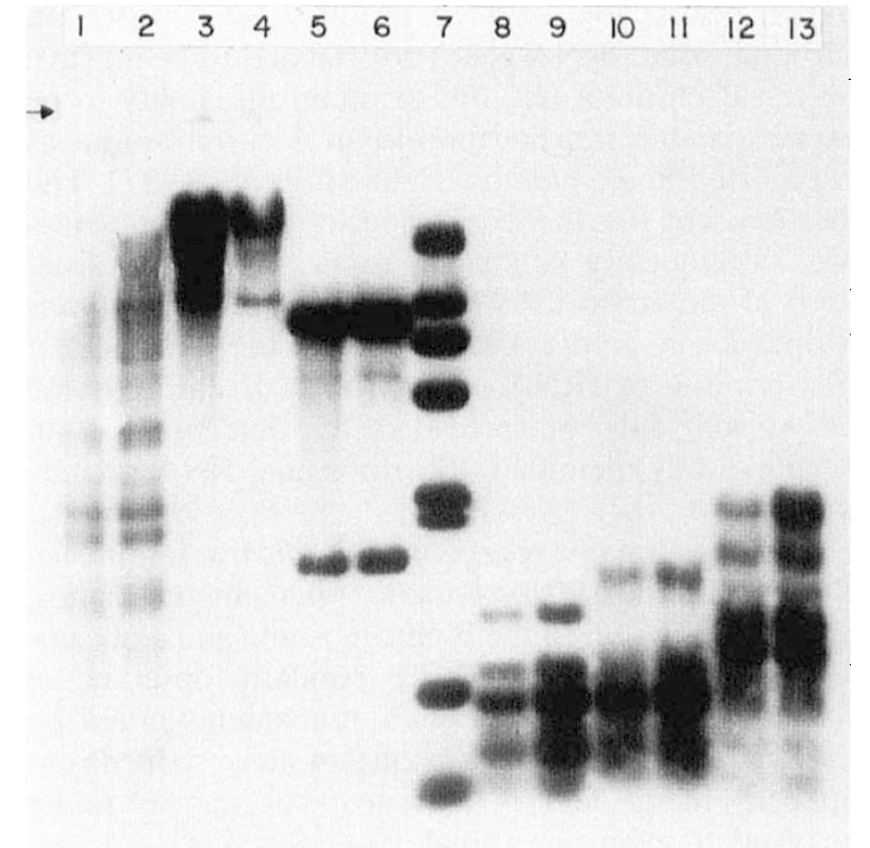

Fig. 3 Southern hybridization of Brachycome dichromosomatica plants containing $0 \mathrm{~B}$ and $2 \mathrm{~B}$ with $18 \mathrm{~S}$ and $25 \mathrm{~S}$ rRNA gene probes. Genomic DNA from $0 \mathrm{~B}$ (tracks 1, 3, 5, $8,10,12$ ) and $2 \mathrm{~B}$ (tracks $2,4,6,9,11,13$ ) were digested with $M s p \mathrm{I}$ (tracks 1,2), HpaII (tracks 3, 4), DraI (tracks 5, 6), MboI (tracks 8, 9), Sau3A (10,11) and HinfI $(12,13)$. Track 7 is lambda bacteriophage DNA-digested with HindIII and labelled with ${ }^{32} \mathrm{P}$ as molecular size standards. The fragments are $23.1,9.4,6.6,4.4,2.3,2.0,0.56$ and $0.13 \mathrm{~kb}$. The origin is indicated with an arrow.

$48 \mathrm{~kb}$ which must be interpreted to indicate that the multiple rRNA genes are heterogeneous for methylation at CCGG sites.

\section{Discussion}

Taken together these results demonstrate a satellited B chromosome in this population of cytotype $A_{1}$ (Watanabe et al., 1975) B. dichromosomatica which carries rRNA genes potentially capable of nucleolus organization. Jones \& Rees (1982) noted that a distinctive feature of Bs was the lack of secondary constrictions with very few exceptions among the 1007 species of plants and 263 animal taxa surveyed. However, recent techniques which allow the detection of ribosomal RNA genes have demonstrated that the B chromosomes of many species have either active nucleolus organizing capacity, assumed from cytological observations (see Green, 1990), or contain sequences complementary to rDNA which are apparently no longer 
transcribed to give an RNA product (Reed, 1993). In addition, some rRNA genes are claimed to be inactive on the $\mathrm{B}$ chromosome but to retain the ability to be expressed after translocation to an A chromosome, as is reported in E. plorans (Cabrero et al., 1987). The location, but not the expression, of rDNA sequences was subsequently confirmed to be within the distal third of the acrocentric B chromosome of $E$. plorans (López-León et al., 1994). Convincing evidence of transcription of rRNA genes from a B chromosome DNA will only be provided by detection of an unequivocally identified $40 \mathrm{~S}$ ribosomal RNA precursor.

The question of expression of B. dichromosomatica $B$ chromosome rDNA remains open. In our hands, associations between the $\mathrm{B}$ chromosome and a nucleolus at diplotene (Fig. 1c) are regularly observed in contrast with the lack of such attachments noted by Carter (1978). In addition, in certain silver-stained root tip cells the B and A chromosomes appear to be involved in organizing a single nucleolus (Fig. 1d).

The complete identity between $0 \mathrm{~B}$ and $2 \mathrm{~B}$ genomic DNA samples for the patterns of hybridization with $18 \mathrm{~S}$ and $25 \mathrm{~S}$ probes shows that this sensitive analysis is unable to distinguish genes on the A and B chromosomes. A total of approximately 30 hybridization bands appear in Fig. 3 indicating that 60 restriction sites were digested. As all except one of the enzymes used were four base cutters, it may be concluded that the A and B rDNA is identical over at least $250 \mathrm{np}$. The similarity in $M s p I$ and $H p a I I$ digestion between $0 \mathrm{~B}$ and 2B DNA samples suggests that $\mathrm{A}$ and $\mathrm{B}$ chromosome rDNA is identically methylated. We conclude, therefore, that the $\mathrm{A}$ and $\mathrm{B}$ chromosome rRNA gene sets are essentially identical and that those on the $\mathrm{B}$ are therefore capable of expression. The intensity of the in situ signals shows that the proportion of B chromosome rDNA in a 2B plant would, if different in sequence or methylation status from the A rDNA, be sufficient to be detectable by Southern hybridization.

This similarity between the A and B chromosome rDNA could indicate an origin for the Bs from the A chromosomes different from that proposed by Carter (1978). He was unable to detect nucleolar organizing activity on the B chromosome and so favoured, on the basis of nucleolar suppression, the idea that they may have arisen by hybridization with a related species, probably one of the cytodemes of Brachycome lineariloba (Carter \& Smith-White, 1972). In fact, the plant material used in these experiments is only one of the four commonly occurring chromosomal arrangements of $B$. dichromosomatica (called $A_{1}$ in Fig. 25, Watanabe et al., 1975), one of which shows NORs on both homologous pairs of $\mathrm{A}$ chromosomes. Therefore it appears more plausible that the $\mathrm{B}$ chromosome originated as a small satellited centric fragment produced during the divergence of these four distinct chromosomal types.

The detection of active ribosomal genes at the distal ends of the B chromosomes of Crepis capillaris, as well as in chromosome 3 , led to the suggestion that the Bs were derived from the latter chromosome (Malusynska \& Schweizer, 1989). However, more recent studies in C. capillaris using a combination of genomic in situ hybridization and in situ hybridization with a variety of probes syntenic with the NOR point to a more complex mode of origin of the $\mathrm{B}$ via a centric fragment from chromosome 1 or 2 and an rDNA transposition from chromosome 3 (Jamilena et al., 1994).

The location and activity of ribosomal RNA genes in $\mathrm{B}$ chromosomes, together with their sequence information, may be useful indicators of the possible origin of $\mathrm{B}$ chromosomes. However, caution is necessary before making conclusions as to gene or chromosome origin from sequence comparisons between rDNA on Bs and As. This is required because it is suspected that tandem repeat sequences, and rRNA genes in particular, evolve in concert (Dover \& Coen, 1981) with some sort of homogenization mechanism operating to remove sequence variants from the repeat family population.

Note: the personal communications consisted of posters of the 1st B-Chromosome Conference, Madrid, Spain, 1993.

\section{Acknowledgements}

We thank Angela Binns for technical assistance. This work is supported by a grant to CRL and JNT from the Australian Research Council.

\section{References}

BEUKEBOOM, L. W. 1994. Bewildering Bs: an impression of the 1st B-Chromosome Conference. Heredity, 73, 328-336.

CABRERO, J., ALCHE, J. D. AND CAMACHO, J. P. M. 1987. Effects of B chromosomes on the activity of nucleolar organiser regions in the grasshopper Eyprepocnemis plorans: activation of a latent nucleolar organiser region on a B chromosome fused to an autosome. Genome, 29, 116-121.

CARTER, C. R. 1978. The cytology of Brachycome. 8. The inheritance, frequency and distribution of $\mathrm{B}$ chromosomes in $B$. dichromosomatica $(\mathrm{n}=2)$, formerly included in $B$. lineariloba. Chromosoma, 67, 109-121.

CARTER, C. R. AND SMITH-WHITE, s. w. 1972. The cytology of Brachycome lineariloba. 3. Accessory chromosomes. Chromosoma, 39, 361-379.

DOVER, G. A. AND COEN, E. S. 1981. Springcleaning ribosomal DNA: a model for multigene evolution? Nature, 290 , 731-732.

GREEN, D. M. 1990. Muller's Ratchet and the evolution of supernumerary chromosomes. Genome, 33, 818-824.

(C) The Genetical Society of Great Britain, Heredity, 74, 556-561. 
HIZUME, M., KITAZAWA, N., GU, Z. AND KONDO, K. 1991. Variation of fluorescent chromosome band in Picea brachytyla var. complanta collected in Yunnan, China. Kromosomo, 2 (63-64), 2149-2158.

JAMILENA, M., RUIZ REJON, C. AND RUIZ REJON, M. 1994. A molecular analysis of the origin of the Crepis capillaris B chromosome. J. Cell. Sci., 107, 703-708.

JOHN, U. P., LEACH, C. R. AND TIMMIS, J. N. 1991. A sequence specific to B chromosomes in Brachycome dichromosomatica. Genome, 34, 739-744.

JONES, R. N. AND REES, H. 1982. B Chromosomes. Academic Press, London.

KAVANAGH, R. N. AND TIMMIS, J. N. 1986 Heterogeneity of cucumber ribosomal DNA repeat units. Theor. Appl. Genet., 72, 337-345.

KIKNADZE, I. I., LOPATIN, O. E., RAKISHEVA, A. ZH. AND MATMURATOV, S. A. 1992. Karyotype characteristics of Chironomus behningi Goetgh. (Diptera, Chironomidae). Siberskii Biologicheskii Zhurnal, 5, 3-11.

LI, S. S., FEI, L. AND YE, C. Y. 1991. Cytogenetic studies on three Oreolalax pelobatoides from Yunnan. Acta Zoologoca Sinica, 37, 216-223.

LOPEZ-LEÓN, M. D., CABRERO, J. AND CAMACHO, J. M. P. 1991. A nucleolus organiser region in a $\mathrm{B}$ chromosome inactivated by DNA methylation. Chromosoma, 100, 134-138.

LOPEZ-LEON, M. D., CABRERO, J., PARDO, M. C., VISERAS, E., CAMACHO, J. M. P. AND SANTOS, J. L. 1993. Generating high variability of B chromosomes in Eyprepocnemis plorans (grasshopper). Heredity, 7 1, 352-362.

LOPEZ-LEÓN, M. D., NEVES, N., SCHWARZACHER, T., HESLOPHARRISON, J. S., HEWITT, G. M. AND CAMACHO, J. P. M. 1994. Possible origin of a B chromosome deduced from its DNA composition using double FISH technique. Chromosome Res., 2, 87-92.

MABUCHI, T. 1991. Nucleolus organisation and meiotic behaviour of $\mathrm{B}$ chromosomes in Hepatica nobilis. Genome, 34, 853-859.
McQUADE, L. R., HILL, R. J. AND FRANCIS, D. 1994. B-chromosome systems in the greater glider, Petauroides volans (Marsupialia: Pseudocheiridae) II. Investigation of B-chromosome DNA sequences isolated by micromanipulation and PCR. Cytogenet. Cell Genet., 66, 155-161.

MALUSZYNSKA, J. AND SCHWEIZER, D. 1989. Ribosomal RNA genes in B chromosomes of Crepis capillaris detected by non-radioactive in situ hybridization. Heredity, 62, 59-65.

MIAO, V. P., COVERT, S. F. AND VANETTEN, H. D. 1991. A fungal gene for antibiotic resistance on a dispensable ("B") chromosome. Science, 254, 1773-1776.

REED, K. M. 1993. Cytogenetic analysis of the paternal sex ratio chromosome of Nasonia vitripennis. Genome, 36, $157-161$.

SALVADOR, L. B. AND MOREIRA-FILHO, O. 1992. B chromosomes in Astyanax scabripinnis (Pisces, Characidae). Heredity, 69, 50-56.

scotT, N. s. AND possingham, J. v. 1980. Chloroplast DNA in expanding spinach leaves. J. Exp. Bot., 123, 1081-1092.

SOUTHERN, E. M. 1975. Detection of specific sequences among DNA fragments separated by gel electrophoresis. J. Mol. Biol., 98, 503-517.

SUJA, J. A., ANTONIO, C., GONZÁlEZ-GARClA, J. M. AND RUFAS, J. S. 1993. Supernumerary heterochromatic segments associated with the nucleolar chromosomes of Pyrgomorpha conica (Orthoptera) contain methylated rDNA sequences. Chromosoma, 102, 491-499.

WATANABE, K., CARTER, C. R. AND SMITH-WHITE, s. 1975. The cytology of Brachycome lineariloba. 5. Chromosome relationships and phylogeny of the race $\mathrm{A}$ cytodemes ( $\mathrm{n}=2$ ). Chromosoma, 52, 383-397.

YONENAGA-YASSUDA, Y., ASSIS, M. D. F. L. D. AND KASAHARA, s. 1992. Variability of the nucleolus organiser regions and the presence of the rDNA genes in the supernumerary chromosome of Akodon aviculoides (Cricetidae, Rodentia). Caryologia, 45, 163-174. 